\title{
ІНТЕРТЕКСТУАЛЬНІСТЬ У СУЧАСНОМУ МЕДІАДИСКУРСІ
}

\section{Каленич В. М.}

\section{ВСТУП}

Медіалінгвістичні дослідження набувають особливої актуальності в сучасній філології, оскільки масмедійний дискурс займає своєрідне місце в соціокультурній парадигмі й інформаційному просторі загалом 3 огляду на зростання ролі інформації як засобу впливу, розмаїтість 3МI, динамічні процеси в масових комунікаціях тощо. В умовах стрімкого розвитку інформаційного суспільства відбуваються різновекторні трансформації медіаконтенту.

Екстра- та інтралінгвальні чинники впливають на формування стилістики медійної сфери. Медіатекст стає унікальним мовним явищем, що дає можливість експліцитно або імпліцитно створити позитивне чи негативне бачення світу.

Різноаспектні виміри тексту, його категорії, способи організації, методи дослідження неодноразово привертали увагу дослідників лінгвістики тексту, літературознавців, культурологів, психолінгвістів, журналістикознавців. Актуальною постає і проблема міжтекстуальних взаємозв'язків і взаємодій, зокрема у сучасному медіадискурсі.

У журналістській творчості автори вдаються до пошуку ефективних експресивних засобів, які не лише б зацікавлювали читача, а й активізували б його пізнавальний потенціал, залучали б до спільного осмислення буття. Одним із таких прийомів $\epsilon$ використання в журналістських творах цитат, перефразувань, покликань на відомі твори, символів тощо, які створюють певні імпліцитні контексти. Інтертекстуальні засоби увиразнюють подання інформації, відіграють специфічну текстотвірну роль, декорують контент ЗМІ різноманітними конотаціями. Інтертекстуальність $є$ критерієм гносеологічної та естетичної цінності тексту.

Залучення інтертекстів у журналістських творах активізує читацьке сприйняття та сприяє конденсації авторської думки. Це своєрідний позатекстовий діалог автора (журналіста, публіциста) й читача, спрямований на більш глибоке розуміння проблеми, іï різновимірні інтерпретації, осмислення буття у відомих образах, ситуаціях. 


\section{1. Джерела дослідження інтертекстуальності в медіатекстах}

Фундаментальні засади теорії інтертекстуальності обгрунтували у своїх працях зарубіжні філологи М. Бахтін, Ю. Крістева, Р. Барт, Р. Якобсон, Б. Гаспаров, Ю. Лотман, М. Фуко, Ж. Дерріда, Ж. Женетт, Н. П'єге-Гро, Н. Кузьміна, Н. Фатеева й ін. Ілюстративним матеріалом для літературознавчої та лінгвістичної наукової парадигми інтертекстуальних прийомів переважно слугували художні тексти.

На думку Н. П’єге-Гро, інтертекстуальність $\epsilon$ «засобом, за допомогою якого один текст перезаписує інший текст, а інтертекст формується з низки текстів, які відображені в певному творі» ${ }^{1}$.

Інтертекстуальність трактують як рекурсивний зв'язок із певними відомими текстами та як проникнення одного тексту до іншого тексту. Розглядаючи основні категорії лінгвістики тексту, О. Селіванова кваліфікує інтертекстуальність «як наявність у певному тексті слідів інших текстів, у більш широкому розумінні - діалогічний зв'язок тексту в семіотичному універсумі 3 попередніми текстами (рекурсивний) та 3 подальшим текстотворенням (прокурсивний)»².

Г. Денисова виокремлює 10 таких функцій інтертексту ${ }^{3}:$ первинний засіб комунікації, засіб створення ігрового моменту, неявний засіб оцінки, прийом переконання реципієнта, засіб комунікативного впливу, своєрідний засіб уведення думок, відправний момент роздумів, контактовстановлюючий засіб, інтерпретаційне знаряддя, спосіб пародіювання, спосіб демонстрації ерудиції і прийом прикрашання тексту.

На думку автора, інтертекстуальність - це доповнення до встановлення зв'язку з читачем, а також спосіб породження власного тексту i утвердження своєї творчої індивідуальності через вибудовування складної системи зв'язків 3 текстами інших авторів. Інтертекстуальність може бути свідомою i несвідомою. Свідома інтертекстуальність постає як стратегія створення змісту, а несвідома наближається до значення інтертекстуальності в широкому розумінні цього поняття ${ }^{4}$.

Останнім часом все активніше дослідники концентрують увагу на медіадискурсі та інтертекстуальних засобах у ньому. Попри різноаспектну досліджуваність публіцистичних текстів, його категорій,

${ }^{1}$ Пьеге-Гро Н. Введение в теорию интертекстуальности / пер. с фр. Москва, 2008. C. 48.

${ }^{2}$ Селіванова О.О. Сучасна лінгвістика: напрями та проблеми. Полтава, 2008. С. 514.

3 Денисова Г.В. В мире интертекста: язык, память, перевод. Москва, 2003. C. $163-178$.

4 Сунько Н.О. Алюзія як маркер інтертекстуальності в англійськомовному газетному заголовку : дис. канд. філол. наук : 10.02.04. Чернівці, 2015. С. 17-18. 
типів, актуальним на сучасному етапі розвитку медіалінгвістики, журналістики $\epsilon$ вивчення інтертекстуальності в українському медіадискурсі. В україністиці питання зв'язків тексту 3 іншими текстами в журналістському творі висвітлювали Н. Зражевська, Т. Іванюха, О. Ільченко, Т. Космеда, О. Костикова, О. Рябініна, О. Цапок та ін.

Медіадискурс привертає увагу науковців своєю динамічністю й багатовимірністю, оскільки віддзеркалює не тільки розвиток соціуму, а й динаміку мовної презентації дійсності. Комунікативна взаємодія «журналіст - читач» опосередкована текстом. Медіатекст може акумулювати в собі інформативність, аналітичність та образність мовленнєвої діяльності автора-журналіста, яка не лише одновекторно зорієнтована на читача, а й вимагає його взаємозворотної реакції і мисленнєвої діяльності.

Англійський мовознавець Алан Белл у праці «Approaches to Media Discourse» зазначає, що визначення медіатексту виходить за рамки традиційного погляду на текст як на послідовність слів. Воно є значно ширшим і включає голосові та звукові параметри, візуальні образи, тобто медіатексти втілюють технології, які використовуються для їх створення та поширення ${ }^{5}$.

Інтертекстуальність стала визначальною особливістю сучасної журналістики. Використання в матеріалах ЗМI інтертекстуальних елементів, з одного боку, зумовлене пошуком найефективніших засобів інформування соціуму, а 3 іншого - дає змогу журналістам створити власний стиль, що набуває актуальності в контексті авторської журналістики.

У сучасних масмедіа вплив перерозподілу статусів адресанта й адресата відобразився на рівні тексту, що зумовило його діалогічність. Важливою рисою іï вираження в медіатекстах є використання деформації прецедентних текстів, котрі $€$ виявом інтертекстуальності. Тобто прецедентні тексти - це такі тексти, що стають основою для створення інтертексту, $є$ відомими для значної кількості різних соціальних груп. Н. Сунько вважає, що поняття прецедентності доцільно розширити охопленням не тільки послідовностей мовних одиниць, а також і певних лексичних одиниць, які $€$ національно-культурними знаками. Такі одиниці можна назвати

${ }^{5}$ Bell A. Approaches to Media Discourse. London : Blackwell Publishers, 1996. P. 35. 
прецедентними іменами. Прецедентні тексти разом із прецедентними іменами отримають статус прецедентних мовних одиниць ${ }^{6}$.

На думку Н. Кузьміної, яка розглядає міжтекстову взаємодію 3 точки зору енергообміну між текстами, і «сильні» тексти мають велику енергоємність. Звідси випливає, що «сильні» тексти володіють високим інтертекстуальним потенціалом, переходячи у формі цитат і алюзій в інші вербальні континууми. Окрім прецедентних, серед «сильних» текстів виділяють також групу текстів, які $є$ цінними поза часовими рамками та соціально-історичними умовами. Такі тексти стають значущими 3 моменту їхнього створення i, на відміну від прецедентних текстів, які актуальні тільки у певний проміжок часу, $\epsilon$ вагомими в різні історичні та культурні епохи ${ }^{7}$.

На особливу увагу заслуговують монографічні дослідження питань міжтекстових зв'язків у журналістських творах і в публіцистиці загалом $^{8}$. У монографії «Інтертекст в масмедійному дискурсі» російський вчений Б. Головко констатує, що «інноваційність інтертексту розкривається через принципи, методи і форми втілення в практику журналізму домінантної ролі дискурсивних процесів, що сприяють організації мислетворчості, мовотворчості й систематизації базових міжтекстових відношень, використовуваних журналістом у ролі універсального інструментарію якісних текстів» ${ }^{9}$.

Аналізуючи семіотику інтертекстуальності публіцистичного тексту, В. Галич зауважує: «Уведення інтертекстуальності в параметри соціального часу i простору розкриває шляхи концептуалізації дійсності та вектори комунікативних i культурних стратегій доби» ${ }^{10}$. Звернення до чужих текстів, на думку дослідниці, пов'язане з прагненням самого автора поглибити свою думку й активізувати експліцитний та імпліцитний зміст твору.

Різноаспектність і поліфункціональність інтертекстуальності в медіадискурсі засвідчують такі дослідження цієї категорії тексту:

6 Сунько Н.О. Інтертекстуальність та прецедентність як репрезентанти публіцистичного дискурсу (на матеріалі заголовків англомовних статей). Вісник Житомирського державного університету ім. І. Франка. 2011. Вип. 58. С. 209.

7 Кузьмина Н.А. Интертекст и его роль в процессах эволюции поэтического языка. Москва, 2007. С. 125.

${ }^{8}$ Головко Б.Н. Интертекст в мас-медийном дискурсе. Москва, 2012. 264 с.; Галич В.М. Семіотика інтертекстуальності публіцистичного твору: соціальнокомунікативна рецепція : монографія. Рівне, 2015. 120 с.; Зелянко С.В. Інтэртэкст у публіцыстычным маўленні. Мінск, 2012. 195 с.; Meinhof U., Smith J. Intertextuality and the Media. From Genre to Everyday Life. Manchester and New York, 2000. 159 p.

${ }^{9}$ Головко Б.Н. Интертекст в мас-медийном дискурсе. Москва, 2012. С. 3.

${ }^{10}$ Галич В.М. Семіотика інтертекстуальності публіцистичного твору: соціально комунікативна рецепція : монографія. Рівне, 2015. С. 4. 
інтертекстуальна парадигма журналістського тексту ${ }^{11}$, інтертекстуальність як жанротвірний чинник у сучасній українській есеїстиці ${ }^{12}$, інтертекстуальність і прецедентність в україномовних 3МІ початку XXI ст. ${ }^{13}$, інтертекстуальність у дискурсі сучасної української преси $^{14}$ тощо.

Дослідниця інтертексту Н. Зражевська зазначає, що існують текстові i мовні прояви інтертектуальності. Текстові прояви передбачають наявність цитат, ремінісценцій, алюзій (експліцитний фрагмент у тексті, імпліцитно пов'язані з ним асоціації), а мовні прояви стосуються присутності в тексті певного функціонального стилю, що веде переважно до забарвлення змісту, композиції, жанру публіцистичного тексту i сприяє виявленню етичних, моральних, професійних та інших аспектів повідомлення ${ }^{15}$.

У своєму дослідженні дискурсу преси О. Рябініна, враховуючи досвід філологів, що займалися міжтекстовими зв'язками, виділяє такі різновиди інтертекстуальності, у кожному 3 яких присутнє відношення «текст у тексті»: власне інтертекстуальність - текст у тексті (цитати 3 атрибуцією/без атрибуції, алюзії, фрейми, перифрази, центонні структури); паратекстуальність - заголовний комплекс як текст у тексті; метатекстуальність - текст про текст у тексті; гіпертекстуальність - текст над текстом у тексті ${ }^{16}$.

Традиційно виділяють такі форми вияву інтертекстуальності, як цитати, алюзії, ремінісценції, мандрівні сюжети, римейки, парадигматика асоціацій, синкретизм функціональних стилів і жанрів тощо ${ }^{17}$. Не всі названі форми вияву інтертекстуальності однаковою мірою проявляються у медійних текстах, адже одні $\epsilon$ досить поширеними і часто вживаними, інші майже не застосовуються при

11 Зражевська Н.І. Інтертекстуальна парадигма журналістського тексту. Стиль i текст. 2007. Вип. 8. С. 89-99.

12 Іванюха Т.В., Полякова Г.О. Інтертекстуальність як жанротвірний чинник у сучасній українській есеїстиці. Держава та регіони. Серія "Соціальні комунікаиї̈». 2015. № 3 (23). С. 43-48.

13 Ільченко О.А. Інтертекстуальність і прецедентність в україномовних ЗМІ початку XXI ст. (на матеріалі метафоричних словосполучень). Лінгвістичні дослідження : зб. наук. праць ХНПУ ім. Г. С. Сковороди. 2013. Вип. 35. С. 155-160.

14 Рябініна О.К. Інтертекстуальність у дискурсі сучасної української преси: лінгвістичний аспект : автореф. дис. ... канд. філол. наук : 10.01.01. Харків, 2008. 18 с.

15 Зражевська Н.І. Інтертекстуальна парадигма журналістського тексту. Стиль $i$ текст. 2007. Вип. 8. С. 89-99.

16 Рябініна О.К. Інтертекстуальність у дискурсі сучасної української преси: лінгвістичний аспект : автореф. дис. ... канд. філол. наук: 10.01.01. Харків, 2008. 18 с.

${ }^{17}$ Цапок О. Інтертекстуальність заголовків черкаських видань. Мовознавчий вісник. Вип. 14-15. С. 332. 
створенні журналістських матеріалів або ж $\epsilon$ поодинокими вкрапленнями у канву текстового блоку засобу масової інформації.

Незвичайні асоціативні висловлювання, прямі та приховані цитати, ремінісценції та алюзії, глибокий підтекст та інші засоби дозволяють авторові посилити ефект журналістського твору, повніше реалізувати власну творчу інтенцію ${ }^{18}$. Закодована у такий спосіб інформація розрахована на спорідненість фонових знань автора та реципієнтів.

Використання інтертекстуальності стало для сучасних засобів масової інформації однією 3 провідних ознак, оскільки журналістські тексти продукують масову культуру, грунтуючись на культурній спадщині, повторенні відомого й актуального у сьогоденні. Це забезпечує глибше усвідомлення написаного, сприяє аналізу й зіставленню подібних явищ та ситуацій, що відбулися у різні часи, але мають однакові наслідки, або сталися 3 однакових причин, або мають однакову модель розвитку.

Присутність інтертексту в публіцистичному тексті показує також майстерність журналіста, його рівень володіння означеною темою, умінням вдало комбінувати претексти і вплітати їх у новий твір.

\section{2. Інтертекстуальні засоби в медіатекстах}

Дослідження контенту інформаційно-аналітичного тижневика «Дзеркало тижня. Україна» (за 2018-2019 рр.) дає підстави визначити різні інтертекстуальні засоби та їхню функціональну специфіку.

Одним зі способів організації тексту й найбільш продуктивних інтертекстуальних прийомів у медіатекстах $є$ цитація - використання в тексті уривку іншого тексту, вислову для ілюстрації, аргументації, підтвердження певної думки 3 дотриманням особливостей чужого висловлення (афоризми, прислів'я, крилаті вислови тощо). Н. Кузьміна розрізняє поняття «цитація» і «цитата». Цитація - процес енергообміну між прототекстом (прототекстами) і метатекстом. Цитата (у широкому значенні) - інтертекстуальний знак 3 високим енергетичним потенціалом, що дає змогу йому просуватися в часі та просторі інтертексту, накопичуючи культурні змісти і з огляду на це збільшуючи імпліцитну енергію ${ }^{19}$.

Цитати, фрагменти цитат або навіть окремі слова чи словосполучення, колись влучно сказані, написані, допомагають злити

${ }^{18}$ Іванюха Т.В., Полякова Г.О. Інтертекстуальність як жанротвірний чинник у сучасній українській есеїстиці. Держава та регіони. Серія «Соціальні комунікації». 2015. № 3 (23). C. 43.

19 Кузьмина Н.А. Интертекст и его роль в процессах эволюции поэтического языка. Москва, 2007. С. 157. 
текстовий матеріал у єдиний твір, водночас спонукають читача спрямувати пізнавальну діяльність у сферу інтертексту і внести в текстреципієнт додатковий смисл. У публікаціях газети «Дзеркало тижня» трапляються прямі (або експліцитні, марковані, атрибутивні) цитати, які містять пряму вказівку на автора чи претекст: «Свого часу відомий німецький публіщист Людвиг Берне сказав: «Справедливість - такий же необхідний для життя продукт, як і хліб» («ДТ». 2018. № 16. С. 2); «Світ - безмежний, і мандрівник - справжній його володар», - писав Гюстав Флобер («ДТ». 2019. № 39. С.14); «Як зауважив іщее Григорій Сковорода, “Чогось найважливімого нам не вистачає». Мандрівний філософ мав на увазі совість» («ДТ». 2019. № 49. С. 15); а також непрямі цитати (або імпліцитні, немарковані, неатрибутивні), які не містять ніяких маркувань: «Подивімося на ситуацію в ОРДЛО і Криму: «На всіх язиках все мовчить, бо благоденствує» («ДТ». 2018. № 24-25. С. 2) - вислів 3 поеми «Кавказ» Т. Шевченка»; «Часу дуже мало, $i$ гаяти його не варто за будь-якого сценарію. Питання стойть иілком по-датськи: «Бути чи не бути?» («ДТ». 2018. № 26. С.8) - вислів 3 трагедії В.Шекспіра «Гамлет».

У медіатекстах використовують також часткові або редуковані цитати в авторській інтерпретаціі: «Громадяни ияієї Скандинавської краӥни були ледь не иоковані «і ланами широкополими, $i$ Дніпром, $і$ кручами» («ДТ». 2018. № 44. С.8); «Однак цุе не означає, щзо роботу в ц̧ьому напрямі слід припинити. Навпаки, потрібно «лупати цюю скалу» $і$ надалі» («ДТ». 2018. № 26. С.7). Такі інтертекстуальні засоби функціонують як прийом мовної гри з елементами аплікації: «А якщо говорити серйозно, то ми вже якось зачекалися «свого Вашингтона з новим і праведнимзаконом». Який усе-все змінить» («ДТ». 2018. № 10. С.2).

Іноді журналісти вдаються до перефразування, що посилює імпресивність висловленої думки: «Однак двічі в історію, як $і$ в річку, не ввійдеш». («ДТ». 2018. №21. С.15); «Перефразовуючи відомий вислів, можна констатувати: "Скажи мені, хто тебе підтримує, $і$ я скажу, хто ти» («ДТ». 2018. №29. С.5); «Перефразовуючи Черчилля, можна сказати, щуо сучасний Захід - це не найліпша конфігурація, частиною якої хотілося б стати, але кращзої людство наразі не вигадало» («ДТ». 2018. № 28. С. 4).

Цитати як інтертекстуальні засоби реалізують текстотвірний потенціал. Наприклад, цитату використовують у ліді статті як іiі проблему або ідею: «Дорослі люблять із глибокодумним виглядом ичитувати Антуана де Сент-Екзюпері: "Bci ми родом з дитинства», коли намагаються довести, щуо пам'ятають про своє дитинство й розуміють важливість тих речей, які необхідні дитині» («ДТ». 2018. № 11. С. 13), а також як резюме у кінці публікації: «I водночас усебічно 
i глибоко розібратися з проблемою щодо системного менеджменту та розробити відповідну змістовну державну або національну програму, спрямовану на покращення ситуачіï<... I тут доречно вкотре згадати слова Едвардса Демінга: «Удосконалюватися не обов'язково. Виживання - справа добровільна» («ДТ». 2019. № 45. С. 7). Такі інтертекстуальні засоби не лише влучно увиразнюють публікацію, а й завжди мають конотативне значення, виражаючи певну оцінку i ставлення до фактів, що підсилює експресивність тексту.

Цитатним обрамленням медіатексту послуговується автор у статті «Лібералізм і консерватизм - Інь і Янь» («ДТ». 2018. № 45. С. 6). У ліді він подає висловлювання знаменитого американського актора і режисера Л. Німого: «Коли у нас немає інформаиії, ми переходимо до найпростішого світогляду, до чорно-білого. Але тоді ми змушені брехати собі. Чорний ніколи не буває таким чорним, яким ви його малюєте, а білий ніколи не буває таким білим». Свої міркування про суспільно-політичний розвиток країни, соціальні норми і цінності автор завершує словами нашого земляка, який народився на території нинішньої Київської області, видатного філософа М. Бердяєва: «Неможливе нормальне і здорове існування і розвиток суспільства без консервативних сил. Консерватизм підтримує зв'язок часів, з'єднує майбутне з минулим».

3-поміж фразеологічного розмаїття медіадискурсу виокремлюємо крилаті вислови, прислів'я, приказки як інтертекстуальні засоби, що афористично узагальнюють авторське світобачення або певні життєві закономірності: «Але правила, як удома, так $і$ в умовах дитячого колективу, мають поширюватися на всіх, включно з дорослими. «Що можна Юпітеру, те не можна бику» - тут аж ніяк не пройде» («ДТ». 2018. № 2. С. 13); «Якщио комусь не подобається це дзеркальне відображення, то варто згадати крилатий вислів: «Нема чого на дзеркало нарікати, якщо пика крива» («ДТ». 2018. № 29. С.12); «Відомий афоризм говорить: «немає нічого більи практичного за хорошу теорію» («ДТ». 2018. № 31. С.7); «Чи пройдуть вони за ідеальною для будь-якого иентру формулою «і вовки ситі, $\boldsymbol{i}$ вівці цілі» - лишається тільки гадати» («ДТ». 2018. № 22. С.5).

Як відомо, заголовок - це елемент медіатексту, який лаконічно, стисло, чітко, конкретно і концентровано відображає тему, головну ідею статті або задум адресанта. Газетні заголовки, функціонуючи в газетному дискурсі, мають прагматичну настанову (запрограмовані здійснити вплив на адресата). Прислів'я та приказки використовують у ролі заголовків публікацій: «Кравець крає, як матерії стає» («ДТ». 2018. № 35. С. 1); «Хоч плюй у вічі - ̈м Божа роса» («ДТ». 2018. № 34. С. 3); «Золоте правило земельної реформи: «сім разів відміряти, 
а один раз відрізати!..» («ДТ». 2018. № 20. С. 8); «Сорок років мак не родив, і голоду не було» («ДТ». 2018. № 7. С. 9); «Що посієи, те й пожнеш» («ДТ». 2019. № 34. С. 13); «Який сусіда - така й бесіда» («ДТ». 2019. № 50. С. 8). Іноді вони бувають усіченими: «...На те й напоролись» («ДТ». 2019. №45. С 12); «Бідні, бо ...» («ДТ». 2019. № 39. С.10). Фольклорна основа робить заголовки емоційними, глибокими, компактними і близьким читачеві. Як інтертекстуальні маркери такі вислови 3 народної творчості вирізняються емоційно-експресивними барвами, але в контексті публікації загострюють проблему з різним стилістичним ефектом (жарту, іронії, сарказму, інтриги тощо).

Особливий комунікативно-прагматичний потенціал мають заголовки, у яких використовуються трансформовані усталені вирази, вирізняючись не тільки експресією, а й своєрідним інформаційним кодом до медіатексту: «Per aspera ad astra Хмельниччини» («ДТ». 2018. № 12. С. 15); «Бійся китайців, які приносять дарунки» («ДТ». 2018. № 32. С .8); «Старий ворог кращий за нових двох?» («ДТ». 2018. № 42. С. 4); «Довго запрягали, а як поїдемо?» («ДТ». 2019. № 37. С.1); «Не такий страшний біпатрид, як його малюють?» («ДТ». 2019. № 40 С. 1); «ГТС сльозами не зарадиш» («ДТ». 2019. № 41. С. 9); «Гроші на науку чи на вітер?» («ДТ». 2019. № 47. С. 1).

Пристосовані до сьогодення й оновлені фразеологізми звучать досить колоритно. Такі оказіональні вирази $є$ упізнаваними, оскільки зафіксовані свідомістю автора і читача як фразеологічні одиниці, однак як елементи мовної гри конотативно ілюструють переосмислення проблеми, порушеної в публікації. Різноманітні трансформаційні потенції фразем, оновлення компонентного складу не заперечують твердження про їхню сталість (кодифікованість), а адекватно реагують на суспільно-мовну динаміку, семантичні зрушення.

Інтертекстуальні цитати мають лінгвокультурну цінність і зорієнтовані на концептуальну, підтекстову інформацію. Одним із інтертекстуальних прийомів $\epsilon$ епіграф, який відіграє особливу текстотвірну роль у журналістських творах на сторінках періодичної преси. Як лаконічний засіб певної оцінки повідомлення він пов'язаний із вмістом публікації і відображає алегорично сформульовану ідею медіатексту, передає його настрій або задає тон, налаштовуючи читача на відповідне сприйняття тексту.

К. Серажим вбачає призначення епіграфа в тому, щоб «визначити основну ідею чи тему, загальний тон тексту. Однак визначити не стільки номінативно, скільки шляхом актуалізації асоціативних зв'язків, проведення аналогій тощо» ${ }^{20}$. Через епіграф «автор відкриває

${ }^{20}$ Серажим К.С. Текстознавство. Київ, 2008. С. 440. 
зовнішню межу тексту для інтертекстуальних зв'язків і літературномовних впливів різних напрямів i епох, тим самим наповнюючи й розкриваючи внутрішній світ свого тексту» ${ }^{21}$.

Наприклад, у газеті «Дзеркало тижня» епіграфами-цитатами до публікацій є такі вислови: «Вмирати в цім житті не вперше, Але і жити спробуй припини». (С.Ссенін) («ДТ». 2019. № 48. С. 10. «Якість життя: феномен півостровів»); «Повірте, що зможете, $-i$ півшляху вже пройдено». (Теодор Рузвельт) («ДТ». 2018. № 50. С. 13. «У грі чи поза грою?»); «Домовилася кішка з мишею, $і$ будинок зруйнувався» (Сирійська приказка) («ДТ». 2018. №34. С.1. «Ідлібський фронт Путіна-Ердогана») та ін.

Автор в епіграфі маскує виховну ідею твору, послуговуючись міркуваннями відомих людей. Наприклад, як композиційний елемент до статті «,Чорна неділя” для захисту авторського права і суміжних прав» («ДТ». 2018. № 33. - С. 9) В. Коноваленко використовує такий загальновідомий афоризм Т. Шевченка: «Якби ви вчились так, як треба, То й мудрість би була своя...». У публікації йдеться про Закон України «Про ефективне управління майновими правами правовласників у сфері авторського права і (або) суміжних прав», який набув чинності 22 липня 2018 року. Зокрема, порушено проблему цивільно-правового захисту авторського права і суміжних прав у судах відповідно до нових норм, відповідальності за порушення тощо.

Займаючи автономну позицію, епіграф служить засобом вираження авторських інтенцій, комунікативно-прагматичної установки автора. Для формування читацької установки важливий не тільки епіграф, а й його походження, зокрема часова, просторова, соціокультурна віддаленість джерела. Найчастіше джерелами епіграфів-цитат у газеті «Дзеркало тижня» $є$ :

- поезія Тараса Шевченка (О. Покальчук «Пароксизм брехні», 2018. № 24. С .16), Валерія Стратонова (В. Меліхов «Харків: перші постріли в спину Української Народної Республіки», 2018. № 16. С.15), Булата Окуджави (В. Мостовий «Вири пам'яті», 2018. № 11. С.10), Ярослава Смелякова (В. Меліхов «Предтеча перебудови», 2018. № 8-9. С. 19) й ін.;

- проза Льюїса Керрола («Аліса в Країні Чудес») (Т. Жибер «Середньострокове бюджетне планування: панацея чи звичайний інструмент?» 2018, № 48. С.6), Альбера Камю («Сторонній») (О. Покальчук «Синдром навченої втоми», 2018. № 20. С. 11), Ернеста

21 Фатеева Н. А. Контрапункт интертекстуальности, или интертекст в мире текстов. Москва, 2000. С. 32. 
Хемінгуея (О. Сліпушко «Моя війна», 2018. № 12. С. 11), Френсіса Скотта Фіцджеральда (В. Горбулін «Вулканічний синдром», 2018. № 23. С. 1);

- висловлювання відомих (i не дуже відомих) діячів політики, культури, науки, зокрема, Теодора Рузвельта (М. Хвесик, А.Сундук «У грі чи поза грою?», 2018. № 50. С. 13), Жана Бодрійяра (Д. Череватський «Увесь цей джаз», 2018. № 47. С. 9), Чарлі Чапліна (О. Ткач «Консервація пенсійної системи. Ще на чотири роки?», 2018. № 45. С. 7, В. Горбулін «Трагікомедія реакцій на „трагедію” у Гельсінкі», 2018. № 29. С. 2), Омара Хайяма (В. Федянін «Іранський прецедент Трампа», 2018. № 33. С. 4), А. Ейнштейна (М. Краснянський «Фактор чавуну», 2018. № 33. С. 12), Леся Курбаса (В.Ткач «Мистецтво грошей як пріоритет довіри», 2018. № 27. С. 12), Миколи Вавилова (Л. Суржик «І все те в пам'яті зерна ...», 2018. № 13. С. 13) й ін.

Загалом механізм дії всіх інтертекстуальних прийомів однаковий: експліцитний фрагмент чи поняття в тексті й імпліцитно пов'язані 3 ними асоціації. Як автономні смислові одиниці вони актуалізують важливу для читача інформацію, апелюючи до його пам'яті, інтелекту, культури, життєвого досвіду.

Алюзії як інтертекстуальні прийоми образності й виразності створюють асоціації за рахунок натяку на досить відомі історичні чи літературні факти, події, фрази, персонажів інших текстів 3 розрахунком на ерудицію читача: «Нам подобається потрапити в історію величних перемін, нехай $і$ на «Титаніку» («ДТ». 2018. № 15. С. 13); «Як тільки усвідомимо, щңо ми - сім'я (причому не Кайдашева), до Кремнієвої долини буде рукою подати» («ДТ». 2018. № 28. С. 3); «Бізнесосвіта: бал - не для нашої Попелюшки?» («ДТ». 2019. № 33. С. 12); «I влаштовувати на ию тему дикі змагання, наче це не артисти й не політики, а маленькі дикуни з «Володаря мух», - уже навіть не постправда, а постклініка» («ДТ». 2019. № 41. С. 14); «Тоді як слід докладати зусиль, щоб від "плачу Ярославни" перейти до конкретних кроків назустріч сотням тисяч родин, які вже забули, щчо це таке підтримка і сильне плече держави» («ДТ». 2019. № 50. С. 15).

Алюзія також може функціонувати як засіб створення якісних характеристик шляхом перенесення рис міфологічних, історичних, літературних персонажів на ті, про які йдеться в медіатексті. Наприклад, у статті «Страусина політика (не) пройде?» («ДТ». 2019. № 46. С. 12) в заголовок винесений інтертекстуальний прийом натяку те, що страус закопує голову в пісок, аби не бачити загрози. Розмірковуючи над тим, чи вкладатиме держава кошти в маленькі школи, автор далі констатує: «Очевидно, питання, що робити з маленькими школами, не можна просто відкласти й сховати голову в пісок, як робилося вже не раз. Потрібна відверта публічна дискусія». 
Алюзія як метафоричний засіб кодування інформації може породжувати асоціації з макроконтекстом претексту - текстом загалом, певними подіями або низкою подій у тексті, вчинками, характером або проблемами персонажів, ідейною своєрідністю твору й ін. О. Проценко підкреслює: «Успішне оперування алюзією вимагає від журналіста неабиякої майстерності, зокрема знання багатого фонду передтекстів, володіння словом, уміння знаходити цікаві паралелі. Із погляду декодування алюзія - це ще й спосіб активізувати глядача, залучити його до співтворчості» ${ }^{22}$.

Алюзія має потужний пізнавальний потенціал, оскільки викликає у свідомості читача два контексти і дві ситуації, тобто асоціативно відсилає до прототексту, звідки взято образ, та збагачує певними конотаціями новостворений текст. Прийом аплікації використовують журналісти в заголовках-алюзіях, які відсилають читача до заголовка відомого твору, але щодо медіатексту зазнають метаморфози: «Перехресні стежки корифеїв украӥнського театру» («ДТ». 2018. № 46. С. 16); «Дивовижний новий економічний світ» («ДТ». 2018. № 49. С. 9); «Мовчання ягнят, або Правда про емоційне насильство» («ДТ». 2018. № 48. С. 13); «Стійкий олов'яний дипломат» («ДТ». 2019. № 40. С. 3); «Битва Давида і Голіафа» («ДТ». 2019. № 50. С. 3); «Відновити довіру до прокуратури: місія здійсненна» («ДТ». 2019. № 50. С. 3).

Інтертекстуальна прагматика властива ономастичним засобам (імена культурних i політичних діячів, літературних персонажів, бібліоніми, міфоніми й ін.): «Якби Джсордж Орвелл дожив до наших днів, він би, напевно, позаздрив таким сюжетам. Тим більше, щзо йдеться не тільки про новий тоdus operandi бізнесу» («ДТ». 2018. № 16. С. 10); «Навіть егоӥстичний творецьь (а бувають інші?) завжди діалогічний, звідси й невдала спроба забути Герострата. Тобто творча особистість тим вільніша, чим ї̈ витвори соціальніші» («ДТ». 2018. № 23. С. 10); «Впровадженню иієї тендениії, яка починає виходити за межі чергової філософської інтоксикації, як ие було в Достосвського, Ніцше $i$ т.д., сприяє бурхливе зростання інформаційних взаємин через Інтернет $i$ специффіка ияих взаємин» («ДТ». 2018. № 29. С. 13); «I тут уже зав'язалася нова глава теорії комічного поза розумінням $i$ осяганням Арістотеля, Крилова та навіть Леоніда Івановича Глібова» («ДТ». 2019. № 41. С. 14). Як приклади алюзії вони образно й символічно передають авторську інтенцію щодо повідомлюваного.

Ремінісценції несуть у собі основну й додаткову оцінну інформацію. Реалізуючись у новому тексті, такі засоби, з одного боку, зберігають

${ }^{22}$ Проценко О. Алюзія в текстах теленовин. Стиль і текст. 2010. Вип. 11. С. 80. 
свій первинний зміст, а 3 іншого - створюють нове контекстуальне смислове поле. Журналістика, широко послуговуючись ремінісцентними образами, «наповнює їх новим понятійним смислом, використовує наявний у них семантичний потенціал для розбудови інтелектуального сюжету чи прагматичної концепції» ${ }^{23}$.

Як стилетворчий елемент медіатексту ремінісценція передбачає уведення до певного твору фрагментів, які нагадують адресатові події, факти, героїв, стилістичні прийоми, мотиви іншого тексту, що може проявлятися в подібності. Так, Ю. Туниця на початку статті «Труба раз, труба два... I балтійській екосистемі - „труба”?» («ДТ». 2018. № 26. С. 12) вдається до літературної ремінісценції: «Дискусї навколо будівництва «Північного потоку-2» нагадують трагічний сюжет оповідання Михайла Старицького «Понизив!», коли сільські хлопияі засперечалися на два відра горілки, чи Петро зіб'є кулею з голови Антона шапку, не простреливши ї̈». Розв'язка цього безглуздого дійства була трагічною, бо «понизив». Потім автор наводить свій коментар щодо порушеної в публікації проблеми: «Щоб сьогодні не «понизити» $i$ не поцілити нищівним ударом в унікальну екологічну систему Балтійського моря, маємо акцентувати увагу не на економічних і політичних інтересах, як ие відбувається досі («шапка» ŭ «горілка»), а на високій імовірності масштабної екологічної катастрофи в Балтійському регіоні («голова»)».

Такі позасюжетні елементи не порушують архітектоніки тексту, а є ліричними відступами, композиційними паралелями. Наприклад, у статті «Щоб жити як європейці...» («ДТ». 2018. №31. С.8) автор згадує казку про старого Хотабича: достатньо було лише одного його бажання, щоб отримати фантастичні результати. I коли Хотабича попросили про телефон, то в одну мить 3'явився такий самий телефон, як і інші, але його було зроблено із... суцільного мармуру. Схожий зовні, він не міг виконувати функції телефону, бо, повторивши форму апарату, Хотабич не зміг відтворити його суть, адже не мав відповідних знань. Автор підсумовує: «Подібне відбувається i в українській економіці. Частенько ми намагаємося відтворити те, що бачимо зовні, тобто форму, не осмислюючи суті предметів і явищ».

Наявні у свідомості автора думки, сюжети, образи відтворюються за допомогою відомих виразів, образів осіб, подій, трансформуючись у контексті, висвітлюючи проблеми у певному ракурсі, іноді завуальовуючи сьогодення або викриваючи його через відгомін минулого. Категорія інтертекстуальності орієнтована на соціокультурну компетенцію читача, не лише на його сприймання текстової інформації, а й ретроспективний погляд в інші тексти. Автор апелює до

${ }^{23}$ Михайлин І.Л. Основи журналістики. Київ, 2011. С. 277. 
підсвідомості читача, у якій зберігаються когніції, пов'язані з інтертекстами. У разі відсутності таких знань читач прагне заповнити невідоме шляхом пошуку першоджерел нерозкодованих інтертекстів у літературі, культурі, історії, науці тощо.

Ефективність інтертекстуального мислення залежить від комунікативно-когнітивної компетентності автора i читача. Використовуючи певні інтертексти, автор, $з$ одного боку, вдається до економії мовних засобів, а 3 іншого - зважає на особливості їхнього сприйняття, розуміння й наслідки впливу на реципієнта. Комунікативно-прагматичні інтенції авторського задуму орієнтовані на те, щоб для висвітлення порушеної проблеми дібрати найвиразніші мовні засоби, які б експліцитно та імпліцитно впливали на свідомість читача, його когнітивну й емоційну сфери, стимулювали мисленнєву діяльність, компенсували ерудицію новими знаннями.

\section{ВИСНОВКИ}

Робота над медіатекстом $є$ головною складовою частиною всього журналістського творчого процесу, де кожен автор шукає власний підхід. Одна тема ніколи не може бути реалізована однаково. Це залежить від рівня підготовки, творчого потенціалу й напрацьованого матеріалу автором, зокрема журналістом, публіцистом. Можна поновому розкрити суть питання, зацікавити аудиторію, використавши у публікації інтертекстуальність - вкраплення у певний текст частин інших текстів.

Активне використання засобів інтертекстуальності на шпальтах періодичних видань зумовило зацікавлення дослідників, тому зараз відбувається активізація досліджень інтертексту не лише у художній літературі, а й у медіадискурсі. Науковці різносторонньо підходять до вивчення цього явища, по-різному його трактують, розглядають функції, роль, стилістичне призначення, 3'ясовують джерельну базу інтертекстем у масмедіа.

Інтертекстуальні засоби і прийоми не лише урізноманітнюють і увиразнюють журналістські матеріали. Вони звертають увагу на найбільш потрібне $з$ того, про що мовиться у тексті, підкреслюють чи спростовують погляди автора або ж героїв публікацій. Інтертекст допомагає лаконізувати виклад думок, зробити його більш цікавим, досконалим.

Наявність цитат у медіатекстах пов'язана 3 їхньою здатністю активізувати інтелектуальний досвід адресата, оскільки цитата $\epsilon$ двоплановою. Вона одночасно відсилає до тексту й контексту відомого джерела і до змісту того тексту, в якому вона наведена. Тому цитування $є$ одним із прийомів створення інтертекстуальності. Алюзія реалізується переважно за допомогою слів або фраз, значення яких асоціюється 3 певною подією або особою, та є одним із прикладів 
мовної гри. Ремінісценції більш рельєфно відображають висвітлювані проблеми, слугуючи композиційними й асоціативними паралелями між інтертекстом і медіадискурсом.

\section{АНОТАЦІЯ}

Категорія інтертекстуальності виявляє відкритість сучасного медіадискурсу до інших текстів. Актуальними постають проблеми вираження інтертекстуальності в сучасних медіатекстах, своєрідності джерел різних видів інтертекстуальних засобів, композиційної ролі інтертекстуальності в масмедіа.

Залучення інтертекстів у журналістських творах активізує читацьке сприйняття та сприяє конденсації авторської думки. Це своєрідний позатекстовий діалог автора (журналіста, публіциста) й читача, спрямований на більш глибоке розуміння проблеми, іiі різновимірні інтерпретації, осмислення буття у відомих образах, фактах, ситуаціях.

Основними інтертекстуальними засобами в медіатекстах $є$ цитати, алюзії та ремінісценції як вдалі прийоми міграції сюжетів, подій, осіб, висловів у контексті журналістських матеріалів. Такі міжтекстові взаємодії створюють емоційно переконливий соціокомунікативний ефект, завдяки зверненню до вічних образів влучно, економно й точно окреслюють ситуацію. Різні прийоми інтертекстуальності змістовно збагачують основну текстову інформацію, слугують для ілюстрації, аргументації, підтвердження певної думки, створюють асоціативні зв'язки 3 уже відомими текстами, увиразнюють авторську позицію, розширюють світогляд читача, стимулюють до роздумів. Інтертекстуальні засоби створюють смислову перспективу, посилюють емоційність тексту. Потрапляючи в новий контекст, відомі образи, символи, фрази реалізують нову експресивну енергію, змінюють свою стилістику.

\section{ЛІТЕРАТУРА}

1. Галич В.М. Семіотика інтертекстуальності публіцистичного твору: соціально-комунікативна рецепція : монографія. Рівне, 2015. 120 с.

2. Головко Б.Н. Интертекст в мас-медийном дискурсе. Москва, 2012. $264 \mathrm{c}$.

3. Денисова Г.В. В мире интертекста: язык, память, перевод. Москва, 2003. 298 с.

4. Зелянко С.В. Інтэртэкст у публіцыстычным маўленні / навук. рэд. В. І. Іўчанкаў. Мінск : БДУ, 2012. 195 с.

5. Зражевська Н.I. Інтертекстуальна парадигма журналістського тексту. Стиль і текст. 2007. Вип. 8. С. 89-99.

6. Іванюха Т.В., Полякова Г.О. Інтертекстуальність як жанротвірний чинник у сучасній українській есеїстиці. Держава та регіони. Серія «Соціальні комунікацї̈». 2015. № 3 (23). С. 43-48. 
7. Ільченко О.А. Інтертекстуальність і прецедентність в україномовних 3MI початку XXI ст. (на матеріалі метафоричних словосполучень). Лінгвістичні дослідження : зб. наук. праць ХНПУ ім. Г.С. Сковороди. 2013. Вип. 35. С. 155-160.

8. Кузьмина Н.А. Интертекст и его роль в процессах эволюции поэтического языка. Москва, 2007. 272 с.

9. Михайлин І.Л. Основи журналістики. Київ, 2011. 496 с.

10. Проценко О. Алюзія в текстах теленовин. Стиль $і$ текст. 2010. Вип. 11. С.72-81.

11. Пьеге-Гро Н. Введение в теорию интертекстуальности / пер. с фр. Москва, 2008. 240 с.

12. Рябініна О.К. Інтертекстуальність у дискурсі сучасної української преси: лінгвістичний аспект : автореф. дис. ... канд. філол. наук : 10.01.01. Харків, 2008. $18 \mathrm{c}$.

13. Селіванова O.O. Сучасна лінгвістика: напрями та проблеми. Полтава, 2008. С.514.

14. Серажим К.С. Текстознавство. Київ, 2008. 528 с.

15. Сунько Н.О. Алюзія як маркер інтертекстуальності в англійськомовному газетному заголовку : дис. ... канд. філол. наук : 10.02.04. Чернівці, 2015. 227 с.

16. Сунько Н.О. Інтертекстуальність та прецедентність як репрезентанти публіцистичного дискурсу (на матеріалі заголовків англомовних статей). Вісник Житомирського державного університету ім. І. Франка. 2011. Вип. 58. С. 208-212.

17. Фатеева Н.А. Контрапункт интертекстуальности, или Интертекст в мире текстов. Москва, 2000. 280 с.

18. Цапок О. Інтертекстуальність заголовків черкаських видань. Мовознавчий вісник. Вип. 14-15. С. 331-336.

19. Bell A. Approaches to Media Discourse. London : Blackwell Publishers, 1996. 230p.

20. Meinhof U., Smith J. Intertextuality and the Media. From Genre to Everyday Life. Manchester and New York : Manchester University Press, 2000. 159 p.

Information about the author: Kalenych V. M. Candidate of Philological Sciences, Associate Professor, Associate Professor of the Department of Journalism, Advertising and Public Relations Vinnytsia Mykhailo Kotsiubynskyi State Pedagogical University 32, Ostrozkyi str., Vinnytsia, 21100, Ukraine 